\title{
Effects of Social Capital on Cocoa Production in Cameroon
}

\author{
Mbu Daniel Tambi ${ }^{1}$, Muluh Mildred Lum ${ }^{1}$
}

\begin{abstract}
This study has as objectives: to examine the impact of social capital in the enhancement of cocoa production in Cameroon, explore the determinants of social capital and to discuss the challenges faced by producers in cocoa production. Methodologically, we have constructed a social capital indicator using Multiple Correspondence Analyses. Primary data is collected in the cocoa zone and probit model use to estimate the result. The result revealed a strong correlation between social capital and agricultural production while the level of education, gender, marital status, financial status, experience in farm activity, household size and agricultural training are strongly corroborating with social capital. In addition, farm size, level of education, application of fertilizers, modern equipment, climate change, access to credit and land tenure system are observed to be the major challenges of farmers in this cocoa zone. We suggest that the decision makers should promote social networking among farmers in the zone.
\end{abstract}

Keywords: Effects, Social Capital, Production, Cocoa zone.

DOI : https://doi.org/ 10.30596/ijbe.v2i1.3481

JEL Classification: Q, Q1, Q13

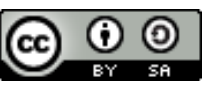

Published by International Journal of Business Economics (IJBE), Indonesia | Copyright (C) 2020 by the Author(s) | This is an open access article distributed under the Creative Commons Attribution License http://creativecommons.org/licenses/by/4.0), which permitsunrestricted use, distribution, and reproduction in any medium, provided the original work is properly cited.

Cite this article as:

Tambi, M. D., \& Lum, M. M. (2020). Effects of Social Capital on Cocoa Production in Cameroon. International Journal of Business Economics (IJBE), 2(1), 1-17.

${ }^{1}$ Department of Agricultural Economics, 


\section{International Journal of Business Economics (IJBE)}

Vol, 2 Issue 1, pp 1-17, Sept 2020

http:/ /jurnal.umsu.ac.id/index.php/ijbe

eISSN 2686-472X

\section{INTRODUCTION}

Agriculture which is referred to as the science and arts of cultivating crops and the rearing of animals for consumption or for sale is the most space consuming activity and one of humanity's oldest professions. It plays a prominent role in the economy of every country in the world, Africa and sub-Saharan Africa in particular. Most countries in subSaharan Africa have the human and natural resources needed for strong and sustainable agricultural development, thus making most governments to put agriculture at the top of their development priorities. Cocoa production in Cameroon as an agricultural crop is a principal cash crop (Laan and Haaren, 1990).

In the real sense, Cocoa comes from two Greek words: theo (gods) and broma (foods) literal meaning; "food of the Gods". It is a highly competitive and lucrative economic cash crop ranked highest in terms of income generation amongst other agricultural activities in the global markets (UNCTAD, 2004). Cocoa contains butter $(54 \%)$, protein $(11 \%)$, cellulose $(9 \%)$, pentosan $(7.5 \%)$, tannin $(6 \%)$, water $(5 \%)$, theobromine (1.2\%), sugar (11\%) and caffeine $(0.2 \%)$. Traveling along a global supply chain, cocoa beans go through a complex production process that includes farmers, buyers, shipping organizations, processors, manufacturers, chocolatiers, and distributors. Cocoa thus is a cash crop and critical export for producing countries and is also a key import for consuming countries. Thus, it is a crop consumed worldwide but only grown in specific regions, lying within $10^{\circ} \mathrm{N}$ and $10^{\circ} \mathrm{S}$ of the Equator, although it has been grown successfully in India at $14^{\circ} \mathrm{N}$ and has also been attempted in Brazil at $24^{\circ} \mathrm{S}$. For these reasons the plant is grown by a very few countries, a majority of which are located in Africa. Africa alone supplies $75 \%$ of world cocoa, with the highest producer in the region being Côte d'Ivoire providing 35 percent to the total production while Cameroon comes fifth on the list with a 5.3\% share in total production (Fuleh, 2013).

In Cameroon, cocoa was introduced in Mount Fako in $1886 / 1887$ by the German colonial occupiers who managed its production and exportation as raw materials for their home industries. After the overthrow of the Germans by the French and British in 1922, management shifted to the French in the Littoral, Centre and South regions and to the British in the South West Region. Later in 1956 the National Producing Marketing Board was set up in the south West region and the Stabilization Fund in the Centre-South region. While the former was charged with providing farmers with subsidized (farm inputs) and marketing their products, the latter was a policy instrument served to stabilize prices. During this period many private farms began to emerge in other regions of the country characterized by a patriarchal management approach while the management of stateowned farms gradually shifted from an autocratic to a landowner-farmer contract system, accompanied by privatization (Laan and Haaren, 1990).

However, cocoa is mainly produced in the southern segment of the country (south west region, littoral, part of west, center and south regions) which favor its cultivation. In the west region, Santchou is the most important cocoa producing part of the Mbo basin. Moreover, $90 \%$ of the rural population is estimated to be engaged in small-scale agriculture in Cameroon (Robiglio et al., 2010) including cocoa production. Cocoa remains the main cash crop to more than 75 percent of the population in Cameroon. In addition, cocoa production is a delicate process, as the trees are susceptible to changing weather patterns, diseases, and insects, yet they lack access to finances to handle all of these. Besides, cocoa has historically been a key economic sector and a major source of 


\section{International Journal of Business Economics (IJBE)}

Vol, 2 Issue 1, pp 1-17, Sept 2020

http:/ /jurnal.umsu.ac.id/index.php/ijbe

eISSN 2686-472X

export and fiscal earnings (Bulir, 1998). In recent years, cocoa production is more than doubled, from 395,000 tons in 2000 to 740,000 tons in 2005, contributing 28 percent of agricultural growth in 2006 from 19 in 2001 (Bogetic et al., 2007). In West African countries however, Cocoa is one of the most widely produced agricultural cash crops. It is a vital source of foreign exchange, investment, and economic growth. The cocoa proportion portions of the forest agro ecology in Cameroon, Nigeria, Ghana and Cote d'Ivoire now account for over 2 million tons of cocoa which represents 75 percent of world supplies. Cocoa production raises over $\$ 2$ billion in foreign exchange for the sub region and taxation of the sector generates significant government revenues. With average country yields between 300 and 400kg per hectare, approximately 7 million hectares of land is currently in cocoa production in these countries farmed by approximately 2 million households (Vos et al., 2002).

As already noted in the literature, cocoa production can only be increase through the acquisition of capital that can easily be gotten from financial institutions or social network, on what is practically known as social capital. Social capital can be seen as one's perception about community members' solidarity, fairness and trust and each member's willingness to live by the norms of community as well as more or less active participation into community activities (Bowles and Gintis, 2002). Moreover, Dasgupta (2002) looks at social capital as a system of interpersonal networks which enhances cooperation and collaboration that helps to create economic opportunities. This study considers social capital as interactions and ties that exist amongst a community and how each member of this community makes use of the accrued benefits. Social relationships can therefore play an important role in the daily lives of farming households, especially in Cameroon where these relationships can help bridge the numerous challenges facing self-sufficiency in cocoa production. In addition, because of the need for purchased inputs to achieve on-farm yields, and high quality requirements throughout the supply chain to be competitive in world markets, processed product such as cocoa require a great deal of coordination to be produced, processed, and marketed competitively. Unfortunately, the consequent denial of access to affordable credit is probably the major constraint facing the farmers in developing countries in general (Killick, 1999) and specifically, cocoa farmers in Cameroon.

Social capital has the potential of yielding streams of benefits that will lead to a more efficient, innovative and even expanded cocoa production. Social relationships can therefore create a means through which cocoa farmers can in a collective manner foster their efforts toward the enhancement of developing their enterprises (Fuleh, 2013). The lack of finances to support cocoa farmers, such as the lack of adequate credit facilities and rural banking infrastructure has become a major problem for cocoa farmers (Fuleh, 2013). A very limited proportion of farmers actually have access to formal credits. Smallholders frequently lack collaterals to obtain investment capital. Unofficial lenders are a significant source of credit in kind (inputs) or in cash but often demand extremely high interest rates and farmers have little choice and bargaining power as there are often only one or two traders in a village.

An alternative way to solve this problem is to seek for social capital (Agboola et al., 2016) through social ties and networks. However, there are a number of research works on social capital in relation to agricultural production such as Wolz et al (2005) in Poland and Bogetic et al (2007) in Central Zambia, Iyanda (2014), Ajani et al (2009) and Akpabio (2008) in Nigeria as well as Nyemeck et al (2008) to name a few, demonstrating that social 


\section{International Journal of Business Economics (IJBE)}

Vol, 2 Issue 1, pp 1-17, Sept 2020

http:/ /jurnal.umsu.ac.id/index.php/ijbe

eISSN 2686-472X

capital has a positive effect on agricultural production and living standards. However, in Cameroon, such work is yet to be verified, in addition in Cameroon, none has looked at cocoa production from the perspective of social capital. This study is closing this gap by examining the following objectives: to assess the role of social capital in promoting cocoa production in the Santchou zone, explore the determinants of social capital as well as determine the challenges faced by cocoa farmers in Santchou cocoa zone, Cameroon.

Issues related to social capital, have been tested in different domains of agriculture. In Nigeria, Iyanda et al (2014) attempted to verify the effect of social capital on access to credit among cassava farming households in Ogun State. Considering, different dimensions of social capital such as: density of membership index, cash contribution index, labour index, decision making index, meeting attendance index and heterogeneity index and obtained indices between 35.5 and 57.3 percent respectively. They also observed that some 44.2 percent and 35 percent of respondents' sourced capital were from personal savings and rotating savings and credit associations respectively, while the mean credit granted represents 45.5 percent of credit needed. Among Farmers in Poland, Wolz et al (2005) worked on the impact of social capital on farm and household income, in their analysis they aimed at identifying social capital as an independent factor influencing agricultural gross farm income. The variable "passive participation" is associated with too many other variables in order to be linked significantly with one factor. The degree of active participation is closely linked with the level of education. This seems plausible as the higher the level of education, the more likely farmers in Poland are ready to be elected to one of their self-governing positions. Hence, they concluded that social capital has a significant influence on the level of agricultural gross farm income among individual farmers (Wolz et al., 2005).

Investigating social network on economic outcome of farming households and establish the relationship that exist between household welfare and social capital, Adepoju and Oni (2012) provides empirical evidence that social capital and its dimensions have an effect on household welfare. It is evidenced that education can complement social capital in improving household welfare. Moreover, Cordaro and Desdoigts (2016) conducted a research on learning versus status quo bias and the role of social capital in technology adoption, with case study on cocoa farmers in Côte d'Ivoire. They concluded that, an average yield three to four times below what they could quite easily obtain, they also observed that the individual social capital of a community member is positively associated with the benefits he derives from interacting with peers within farming organizations. According to them, weak ties built up across members of farming organizations (e.g., cooperatives) appear to be more conducive to both information exchange and new technology adoption than are stronger ties developed among family or Diaspora members (Cordaro and Desdoigts, 2016).

Besides, Cramb (2004) carried out a study on the role of social capital in the promotion of conservation farming: case of land care in the southern Philippines. He saw that New-style conservation measures such as contour hedgerows or natural vegetative strips were designed to permit small-scale adoption by individual landholders without major outside investment or coordination. His study reveals that the major factors influencing adoption of contour barriers in Barangay Ned were participation in farmerbased, group training events and membership in land care groups. In addition, Farmers drew on their stocks of bonding social capital to form local land care groups, primarily in order to invest in the bridging social capital provided by the Land care Association and the 


\section{International Journal of Business Economics (IJBE)}

Vol, 2 Issue 1, pp 1-17, Sept 2020

http:/ /jurnal.umsu.ac.id/index.php/ijbe

eISSN 2686-472X

land care facilitators. Their result was confirm by Pretty (2003) noting that investing in social capital is a prerequisite to achieving better outcomes in natural resource management. While in Kwara State, of Nigeria, Agboola et al (2014) examined the effects of social capital and access to micro credit on productivity of arable crop farmers. In their study, the different credit sources available to farmers were banks, cooperative societies, local moneylenders, government agency, friends and family in decreasing order of importance. The analysis of social capital and access to credit on the arable crop farmers' productivity revealed that active participation in decision making and credit time lag actually decreased productivity. Their study concluded that social capital and access to credit had positive influence on productivity and was an important factor in improving the income of members of local institution.

Focusing on cocoa production, Bogetic et al (2007) studied the role of cocoa in Ghana's future development and found out that increasing cocoa production by around 60,000 tons per annum is needed to support Ghana reaching its middle-income country target. They also observed that even with complimentary growth in other sectors, cocoa has continued to dominate agricultural exports over the medium term and that structural diversification remains a key challenge for Ghana. Still in Ghana, Darkwah and Verter (2014) analyzed cocoa bean production with the main aim of determining the relationship between annual cocoa output and some selected variables that are likely to stimulate cocoa production in the country. Their result from Johansen co integration test showed a long-run Equilibrium relationship between cocoa bean productions, area harvested, World price and cocoa export, all the variables were statistically significant. While the result from the OLS linear regression showed a positive relationship between annual cocoa bean production and area harvested as well as cocoa export. In a cross section study, Nyemeck et al (2007) discusses the situation of cocoa in Nigeria, Cameroon, Ghana and Ivory Coast in relation to access to credit. They observed that, when loans are made available to cocoa farmers without much emphasis on collateral security, the problem of poor harvest will become history as smallholder cocoa farmers will be empowered to go for any chemical without concern for the cost. Their survey showed that about 54 percent of cocoa farmers in Nigeria have access to credit, 37 percent in Cameroon, while in Ghana and Ivory Coast, only a few cocoa farmers have access to credit. In this perspective, Amin (2001) ascertained that the main cash crop which provides about 40 percent of Cameroon's export is cocoa.

\section{METHODS}

\section{Presentation of Research Area}

The Santchou cocoa zone is located in the West region of Cameroon. The zone covers an area of $335 \mathrm{~km}^{2}$ with a total population of 46249 inhabitants in 2005 . The climate of this zone is equatorial climate of the guinea type and consists of four seasons of unequal durations: big rainy season (mid-August-October), small rainy season (marchJune), big dry season (mid-October - March) and the small dry season (June -mid August). The annual temperature varies between 20.83 to $23.35 \mathrm{~mm}$. The relief of the Santchou community is very contrasting and occupies three zones: base altitude zone (< $700 \mathrm{~m})$, middle altitude zone $(700-1000 \mathrm{~m})$, upper altitude zone $(>1000 \mathrm{~m})$ and urban space (base zone altitude). The soils of Santchou community are distributed in function of the altitude as follows: Hydromophes found in the base altitude zone, ferraliti in the upper altitude zone, limonouse texture or muddy sand and Humifieres in the middle altitude 


\section{International Journal of Business Economics (IJBE)}

Vol, 2 Issue 1, pp 1-17, Sept 2020

http:/ /jurnal.umsu.ac.id/index.php/ijbe

eISSN 2686-472X

zone, and the humifiere horizon here is a little important, is covered by the forest and occupied by coffee exploitations. This zone is favorable for the cultivation of robusta coffee, cocoa, palm oil and many live cultures.

In relation to data, we have made use of both primary and secondary data. However, our major focus has been the primary data which was our computed data in the study. The data for this study was collected through a detailed questionnaire which was administered to 150 farmers of the Santchou zone cultivating the cocoa crop. The questionnaire was personally administered with the help of some trusted postgraduate students under strict coordination. Field visits to the zones were organized every morning and evening to meet the farmers in their homes, farms, churches, market and some specific street corners. In this process, quantitative data was collected and analyzed in STATA 13.0 software. We equally collected some qualitative data that was interpreted directly to permit us to achieve reliable results. The actors chosen to respond to the questionnaire are typical farmers cultivating the cocoa crop. Our study considers both men and women working in the agricultural farms. The method used here was the purposive sampling method; this method consists of choosing members of the sample population at random, thus, every member has the same chance of being a part of the sample population. Those considered for the survey were presented in a questionnaire of 21 questions after intense interview, other relevant information judged necessary but not included in the questionnaire was collected during the interview process and by the end of the sampling exercise over 150 farmers were interviewed.

\section{Econometric Issues}

As seen in the theoretical framework, we made use of the economic model of the family developed by Becker (1965) and as applied by (Frijters et al., 2008). This forms the conceptual basis for our analysis of the contribution of social capital on agricultural production. Based on these authors, the relationship between social capital and cocoa production can be described within the framework of a simple household production model (Blau and Grossberg, 1990). Thus, the generic model of cocoa production for farmer $i$, is assumed to be:

$$
C P_{i}=\lambda_{1} \chi_{i}+\delta_{1} S C_{i}+\varepsilon_{1 i} \ldots \ldots \ldots \ldots \ldots \ldots \ldots(1)
$$

Where is a binary variable representing Cocoa Production, is a vector of household characteristics such as: sex of farmers, ownership of land, financial status, education, access to credit, etc. These are factors believed to be influencing cocoa production apart from social capital, is social capital, is a random error term and the coefficient is the parameter of primary interest and represents the impact that social capital has on cocoa production. Thus social capital is our independent variable.

The equation above reports the probit estimate that measures the marginal effects of social capital on cocoa production. The probit estimate is an appropriate estimate in this type of a study because it attempts to capture the impact of any social capital addition to a farmers ability or know how being formal or informal on production. However, this singleequation estimate may be upward or downward biased depending upon the effect that 


\section{International Journal of Business Economics (IJBE)}

Vol, 2 Issue 1, pp 1-17, Sept 2020

http://jurnal.umsu.ac.id/index.php/ijbe

eISSN 2686-472X

social capital has on agriculture and on the correlation between omitted variables and farmers social capital. For example, if social capital has a positive impact on cocoa production, then we would expect the probit estimate of to be biased upward. To avoid this problem, we have seriously scrutinized our selection of variables in the cocoa production equation. This means that our model is void of any biases. The marginal effect of farmer's social capital on cocoa production can be estimated as:

$$
M E\left((\chi)=\frac{1}{N} \sum_{i}\left\langle P\left(C P_{i}=1 S C_{i}=1\right)-P\left(C P_{i}=1 S C_{i}=0\right)\right\rangle\right.
$$

From equation 2, we can calculate the marginal effects of social capital on cocoa production as the average of the marginal effect of everyone in the sample in STATA 13.0 and the result interpreted as a change in the marginal effect. The result may either be presented in percentage or probability of the marginal change effect on the main dependent variable (cocoa production).

\section{The Computation of Social Capital Indicator}

The social capital index has been constructed for the purpose of this study as our main independent variable. This index has been constructed using the Multiple Correspondence Analysis (MCA). The MCA approach has been popularized in the field of multidimensional poverty analysis by (Asselin, 2005) and in current literature MCA is applied in the analysis of multidimensional welfare such as the case of Cameroon by (Njong and Ningaye, 2008). Technically, MCA is obtained by using the standard correspondence analysis on an indicator matrix by selecting the synthetic variable as well as its different modalities comprising the variable. In our case, we used the MCA to construct the composite index for the farmers' social capital index. It should be noted that in this case, the modalities used to construct the synthetic variable respect the fundamental requirements as outlined in (Asselin, 2005). The modalities or indicators used have an ordinal ordering consistent with their contributions in the first factorial axis as stated in the literature.

Regarding our synthetic variable - farmer social capital index, we chose seven indicators and placed them in an increasing ordinal order as follows: professional group, social group, religious group, satisfaction, active member, responsible position, account owner. This indicator has been computed using the MCA and it's the constructed index that we have used in this study to be our social capital variable, the variables used are presented in table 1.

Table 1. Variables Used to Construct a Social Capital Index

\begin{tabular}{ll}
\hline \multicolumn{1}{c}{ Variables } & Modality \\
\hline Do you belong to any professional group e.g. cocoa producing association? & [Yes, No] \\
Do you belong to any social group? & [Yes, No] \\
Do you belong to any religious group? & [Yes, No] \\
Are you an active member of your group? & [Yes, No] \\
Are you satisfied with your association? & [Yes, No] \\
Do you have any responsible position in your association or group? & [Yes, No] \\
Do you have an account in the bank? & [Yes, No] \\
\hline Source: Author &
\end{tabular}




\section{International Journal of Business Economics (IJBE)}

Vol, 2 Issue 1, pp 1-17, Sept 2020

http://jurnal.umsu.ac.id/index.php/ijbe

eISSN 2686-472X

\section{RESULTS AND DISCUSSION}

The result in this study will be presented as follows: socio-economic characteristics of cocoa producers, determinants of social capital, social capital role in the enhancement of cocoa production and the challenges faced by cocoa producers in Santchou zone.

\section{The Socio-Economic Characteristics of Cocoa Farmers}

Describing the characteristics of cocoa farmers in Santchou zone, it is observed that only 20 percent of women were involved in cocoa production contrary to their male counterparts who made up 80 percent. The reason for the domination of men in our statistics is simply for the male willingness and courage to respond to our questionnaire as opposed to the female folk. These women- married, single or divorced - are victims of discriminatory cultural practices and inappropriate legislation which deprived them from either owning land or from inheriting it. Wokia-azi et al (2008) are in support of this view. Moreover, Wokia-azi et al (2008) has shown that gender disparity exists in the cocoa growing communities of Cameroon with women producing about 80 percent of subsistence food on mainly small family and rented holdings to meet family needs and to supply the local markets. Given that cocoa production is manually intensive, the age group involved is $>35$ years and with a higher concentration above 45 years old. The 25 to 35 years age group is characterized by rural exodus, schooling, migration, decision making and job hunting only a handful are usually settled with jobs at this age. About 75.3 percent of cocoa farmers have only been able to attain the primary and secondary education, whereas just 24.7 percent have been to the tertiary level, which is not healthy for cocoa farming.

Considering the marital status, it can be observed from table 2 that majority of cocoa farmers are married (81.3 percent), it can be logically argued that the study area is found in the rural area characterized by early marriages. As regarding land ownership, we observed that 72.7 percent of farmers are owners of the farms they are working which is either obtained as a gift from inheritance or were bought, unfortunately, 85.3 percent of the farmers did not make use of modern equipments, and this may be due to inadequate financial resources. It can be observed that 46.7 percent of farmers have a small household size while 53.3 percent of farmers have a medium and large household, all of which is healthy for cocoa production. We noted that 60 percent of the farmers applied no chemical fertilizer on their farms while only 40 percent could apply as observed in table 2 . This was due to inadequate finance to purchase these chemical inputs.

Table 2. The Socio Economic Characteristics of Cocoa Farmers

\begin{tabular}{lccc}
\hline \multicolumn{1}{c}{ Description } & Frequency & Percent & Valid Percent \\
\hline Level of Education of cocoa farmers & 6 & 4.0 & 4.0 \\
no education & 56 & 37.3 & 37.3 \\
Primary & 51 & 34.0 & 34.0 \\
Secondary & 37 & 24.7 & 24.7 \\
Tertiary & 22 & & 14.7 \\
Farmers who used Modern Equipment & 128 & 14.7 & 85.3 \\
Use equipment & 25 & 85.3 & 16.7 \\
Did not use equipment & 102 & 16.7 & 68.0 \\
Land ownership & 23 & 68.0 & 15.3 \\
small size & & 15.3 & 18.7 \\
medium size & 28 & & \\
Large & & 18.7 & \\
Marital Status of Cocoa Farmers & & & \\
Single & &
\end{tabular}


International Journal of Business Economics (IJBE)

Vol, 2 Issue 1, pp 1-17, Sept 2020

http:/ /jurnal.umsu.ac.id/index.php/ijbe

eISSN 2686-472X

\begin{tabular}{lccc}
\hline \multicolumn{1}{c}{ Description } & Frequency & Percent & Valid Percent \\
\hline Married & 122 & 81.3 & 81.3 \\
$\begin{array}{l}\text { Household Size of Cocoa Farmers } \\
\text { Small }\end{array}$ & 70 & 46.7 & 46.7 \\
Medium & 63 & 42.0 & 42.0 \\
Large & 17 & 11.3 & 11.3 \\
Farmers who used chemical input & & & 40.0 \\
Use chemical & 60 & 40.0 & 60.0 \\
No chemical & 90 & 60.0 & 3.3 \\
Different age groups of farmers & 5 & 3.3 & 6.0 \\
less than 25 years & 9 & 6.0 & 38.7 \\
between 25-35 years & 58 & 38.7 & 52.0 \\
between 35-45 & 78 & 52.0 & \\
greater than 45 & & & \\
\hline
\end{tabular}

\section{The Determinants of Social Capital among Cocoa Producers in Santchou}

Variables such as access to credit, level of education, experience production, financial status, farm size, farm ownership, climate change and modern equipment are strongly correlating with social capital among cocoa producers in Santchou zone. Access to credit is observed to be affecting social capital positively at 23 percent and at $1 \%$ level of significance. Thus, the more the social capital of an individual, the more the individual will have access to credit as seen in the work of Lawal et al (2009). It is observed that education positively correlates with social capital. This implies that the more the farmers are educated, the more will be their stock of social capital and the more likely farmers benefit from their professional groups. This result is consistent with that of Wolz et al (2005). This is accounted for the fact that the higher the level of education of the farmers, the higher is the opportunity that they will occupy strategic positions in the social network and as such will gain connections and social ties to many others. The end result is that, this increased stock of social capital will go a long way to boast cocoa production of the famers.

Generally, people who are financially buoyant are believed to be more interactive and socially connected than those who are poor. This is because they are always influential at their job sites, their groups (social network, religious, professional) in terms of decision making and they equally hold key positions in these organizations/associations. This in turn makes them to highly rely upon for financial assistance thereby creating social ties and increasing their level of social connectivity. However, we can observe that social capital and financial status of the farmers is positively correlating with a coefficient of 5.7 percent and statistically significant at $1 \%$ level. In addition to the aforementioned reason, we can say that the more financially viable a farmer is, the more stock of social capital will they possess. This is also consistent with Wolz et al (2005) who said that when a farmer is in possession of financial services, it will boast farm income.

Table 3. Factors affecting Social Capital in Santchou among Cocoa Producers

\begin{tabular}{lccc}
\hline \multicolumn{1}{c}{ Variable } & Coefficient & $\begin{array}{l}\text { Std Error } \\
\text { Social Capital }\end{array}$ & T- Robust Statistics \\
\hline Access to Credit & $0.229^{* *}$ & 0.110 & 2.087 \\
Sex & 0.090 & 0.094 & 0.956 \\
Education & $0.231^{* *}$ & 0.098 & 2.365 \\
Experience in Cocoa Production & $0.171^{*}$ & 0.101 & 1.701 \\
Marital status & -0.055 & 0.156 & -0.352 \\
Financial status & $0.057^{* * *}$ & 0.104 & 3.547 \\
Household size & -0.039 & 0.117 & -0.335 \\
Agricultural training & -0.008 & 0.090 & -0.085 \\
Farm size & $0.189^{* *}$ & 0.075 & 2.518
\end{tabular}




\section{International Journal of Business Economics (IJBE)}

Vol, 2 Issue 1, pp 1-17, Sept 2020

http://jurnal.umsu.ac.id/index.php/ijbe

eISSN 2686-472X

\begin{tabular}{lccc} 
Farm Ownership & $0.572^{* * *}$ & 0.099 & 5.780 \\
Modern equipment & $0.021^{*}$ & 0.012 & 1.697 \\
Climate change & $0.257^{* * *}$ & 0.077 & 3.350 \\
Constant term & $0.439^{* * *}$ & 0.157 & 2.791 \\
R- Squared & 0.7118 & $\mathrm{n} / \mathrm{a}$ & $\mathrm{n} / \mathrm{a}$ \\
F- Statistics & $81[122,148 ; 0.0000]$ & $\mathrm{n} / \mathrm{a}$ & $\mathrm{n} / \mathrm{a}$ \\
\hline Total observation & & $\mathbf{1 5 0}$ & \\
\hline
\end{tabular}

Besides, farm size is another factor observed to be affecting social capital and positively correlated at $1 \%$ level of significance. Thus, the larger the farm sizes the more the social capital. This is because a large farm entails many labourers to work on it, the more the farmer will require finances to run the farm activities and the more the farmer will need to contact many other farmers and groups in order to learn better techniques for a better and sustainable management. Farm ownership is observed to behave in like manner, moreover, modern equipment is observed to have a positive effect on social capital in our study. It can be seen that this factor is statistically significant at $10 \%$ level. Thus, as the use of modern equipment increases, social capital is also increasing. Climate change is as well observed to be positively correlating with social capital. It is equally observed that farmers' experience in cocoa production has not just a positive but great impact on social capital and this is statistically significant at $10 \%$ level, with a coefficient of 7.1 percent. This implies that the cocoa farmers have had enough experience in its production which has reasonably increased their level of social capital. This is true in that a farmer cannot indulge into cocoa production for long without associating with others or groups of people producing cocoa too. Thus, as time goes by, farmers go to their network be it religious groups, professional groups or even common initiative groups, who are older in the field to seek for more sustainable practices and techniques which will help them better manage their farms and hence boast their production.

However, marital status is observed to have a negative effect on social capital. This means that the more the farmers are married; the lower will be their level of social capital. This is because married people turn to be busy with satisfying each other at the expense of associating and creating social ties with friends, closed family members and the external family. Household size is also seen to negatively correlate with social capital implying the larger the household size, the lower its level of social capital. On the other hand, sex has a positive coefficient of 9 percent, which means that the more the males, the more their level of social capital. This can be observed on table above, which indicates that male farmers make up 80 percent as against their female counterparts. The reasons being that it is generally believed males are more mobile, interactive and have the highest responsibility than females.

\section{Social Capital and Cocoa Production Enhancement}

Verifying the effects of social capital in the enhancement of cocoa production in Santchou cocoa zone, it can be observed that social capital is strongly correlated with cocoa production at a 1 percent significance level and with a probability coefficient of 3.22 percent. Social capitals can thus booster cocoa production as related to the work of Wolz et al (2005). In addition, belonging and actively participating in a professional group, religious group, social group simply means increase in social capital and all of these are associated with much benefit in terms of agricultural production. This is evidenced in the work of Wambugu et al (2009) who studied the effect of social capital on performance of smallholder producer organization case of groundnut growers in western Kenya equally 


\section{International Journal of Business Economics (IJBE)}

Vol, 2 Issue 1, pp 1-17, Sept 2020

http://jurnal.umsu.ac.id/index.php/ijbe

eISSN 2686-472X

and concluded that they were positively correlated. The variable sex equally correlates with cocoa production; we can observe that this variable is positively and strongly correlates with cocoa production at 5\% level of significance and a coefficient of 2.21 percent, implying that more men are involved in cocoa production than females. This is due to the fact that male farmers as the head of households are obviously more energetic than females and so are engaged in cash crop production which is generally more demanding while female farmers are involve in food crop cultivation. In most rural communities, women concentrate with child bearing and the household chores, such as the fetching of water, fuel (e.g. fire wood), serving of food and sanitation of the house, cooking. So the men focus on cash crop cultivation which requires much man power in order to better produce to meet-up with the family and economic exigencies. This result is supported by the work of Wokia-azi et al (2008) who are of the opinion that women are discriminated upon and so cannot own land which reduces their number involved in cocoa production.

Moreover, the educational level of the farmers is another factor that enhances cocoa production. Going by table 5 , we can notice that this parameter positively affects cocoa production at 5\% significance level and a coefficient of 2.01 percent this is because, the more an individual studies the greater the will to apply the knowledge objectively. Farmers with post-graduate education are more likely to adopt sustainable practices. Education therefore creates awareness and increases the desire to be competitive. Furthermore, experience that farmers have got in Cocoa Production will also help show what role social capital has on cocoa production. Farmers' experience plays a positive role in the enhancement of cocoa production at a 1 percent level of significance and 1.77 percent rate of contribution. Besides, financial status of the farmers crucially contributes in enhancing cocoa production at 10 percent level of significance and a coefficient of 1.75 percent. This is because farmers need adequate finances so as to enable them carry on their farming activities and still be able to have some to run their day-to-day activities. The result also holds that, household size can play an important role in cocoa production; this parameter is positive at 5.41 percent in terms of magnitude and statistically significant at 1 percent.

Table 4. Social Capital and Cocoa Production Enhancement in Santchou Cocoa Zone

\begin{tabular}{|c|c|}
\hline Variable & $\begin{array}{c}\text { Probit } \\
\text { Cocoa Production }\end{array}$ \\
\hline Social Capital & $0.016 * * *(3.22)$ \\
\hline Access to Credit & $0.003(1.03)$ \\
\hline Sex & $0.016 * *(2.21)$ \\
\hline Education & $0.079 * *(2.01)$ \\
\hline Experience in Cocoa Production & $1.025 * * *(1.77)$ \\
\hline Marital status & $-0.016(-0.01)$ \\
\hline Financial status & $0.035 *(1.75)$ \\
\hline Household size & $2.021 * * *(5.41)$ \\
\hline Agricultural training & $0.003 * *(1.98)$ \\
\hline Farm size & $3.020 * * *(2.94)$ \\
\hline Farm Ownership & $-0.026(-0.09)$ \\
\hline Modern equipment & $0.005^{\mathrm{m}}(1.63)$ \\
\hline Climate change & $0.002 * * *(7.62)$ \\
\hline Constant term & $0.010^{\mathrm{m}}(1.62)$ \\
\hline Pseudo- $R^{2}$ & 0.8240 \\
\hline LR chi $2 / \mathrm{F}^{2}$ : Prob $>$ chi 2 & $93.41[15 ; 0.0000]$ \\
\hline Total Observation & 150 \\
\hline
\end{tabular}




\section{International Journal of Business Economics (IJBE)}

Vol, 2 Issue 1, pp 1-17, Sept 2020

http:/ /jurnal.umsu.ac.id/index.php/ijbe

eISSN 2686-472X

Smallholder farmers who receive training either through seminar, workshop or direct field had access to agricultural training which enabled them to produce many products at high quality and increase their technical efficiency. The coefficient obtained was 1.98 percent statistically significant at 5 percent level. This indicates that the smallholder farmers who underwent training increased their production of cocoa. This result agrees with Sentumbwe (2007) who found that farmers who got training in better agronomic practices were technically more efficient than farmers who lacked such training. Galawat and Yabe (2011) also found that farmers who attended training were profit efficient, while farmers who did not have any training were inefficient and had low profit efficiency. Equally, Nikaido (2004) observed that the participation of the small scale producers in trainings increased efficiency for small scale industry.

Climate change strongly affects cocoa production at $1 \%$ level of significance and at a very high coefficient of 7.62 percent. Climate change can either be variability of rainfall and temperature. This means farmers were seriously affected by climate change and this climate change is seriously affecting cocoa production, this is supported by the study of Abayomi (2012). Further, farm size strongly enhances cocoa production at $1 \%$ level of significance and at a coefficient of 2.94 percent. This implies that the larger the farm size, the more the cocoa production. In addition, access to credit is observed to have a positive coefficient of 1.03 percent. Modern equipment is equally positive with a coefficient of 1.63 percent showing that it can enhance cocoa production in the study area. This can be accounted for by showing that any farmer in position of a new modern agricultural equipment will seek for ideas to use it and this will always motivate farmers to grasp every opportunity that will enlighten and enable them booster their cocoa production. Besides, farm ownership and marital status have negative coefficients implying that they do not enhance cocoa production in the study area. This is due to the fact that married couples are believed to spread their efforts and so discouraging agricultural production.

\section{The Challenges faced by Cocoa Producers in Santchou zone}

Finances are indispensable to assist farmers to acquire basic agricultural tools, improved planting material, hire labour, transport facilities and do many other things. However, going by table below, out of 150 cocoa farmers interrogated 54.7 percent of them say they face financial difficulties as against 45.3 percent who do not. Thus, the percentage of those handicapped by finances equal 9.4. This makes it difficult to effectively carry out the various activities involved in cocoa production. In addition, training received by cocoa farmers will help boost their technical know-how in agriculture in general and cocoa production in particular. This implies that those who have undergone training in agriculture will obviously apply good agricultural practices leading to higher yields. Unfortunately, the table demonstrates that out of the 150 respondents, up to 76.7 percent of the cocoa farmers have never undergone any training in agriculture meanwhile only 22.3 percent had some training. This therefore gives a percentage difference of 54 percent, which makes up the population that faced challenges in cocoa production as a result of lack of training.

Education is an important aspect of capacity building that influences labour productivity with regard to investment decision making. Farmers who have attained the different levels of education are thus expected to be more performing in cocoa production than those who never went to school at all or who have low levels of education. In this perspective, 96 percent of the cocoa farmers interrogated face challenges in cocoa 


\section{International Journal of Business Economics (IJBE)}

Vol, 2 Issue 1, pp 1-17, Sept 2020

http:/ /jurnal.umsu.ac.id/index.php/ijbe

eISSN 2686-472X

production because of low level of education as against 4 percent of famers who had no such challenge. Therefore, the percentage of those who actually face difficulties given their level of education is 92 percent. Moreover, farm size is another constraint faced by cocoa farmers in Santchou cocoa zone. Despite the fact that most of these farmers are the owners of these farm lands which were either passed unto some of them through succession or were bought by them are of small sizes of mostly half a hectare or a hectare. It can thus be observed from the table that 83.3 percent of cocoa farmers are in possession of farmlands but of small sizes. On the other hand, just 16.7 percent of these farmers have cocoa farms of over two hectares, thus making a percentage difference of 66.6 percent cocoa farmers who really face challenges in cocoa production due to small farm sizes.

Furthermore, another production constraint is the application of nutrients. Most of the cocoa farmers are unable to apply substantial amounts of fertilizers in their farms because of lack of financial means. Cocoa needs both chemical and organic nutrients and the nutrients exported by harvested beans and pods equally need to be replaced in order to have high yields. According to Coulibaly (2012), the cocoa plant grows best on high nutrient content coarse soil with a depth of $1.5 \mathrm{~m}$ allowing for good root development, water retention and drainage. A pH of 5.0 - 7.5 with 3.5 percent of organic matter in the top 15 centimetres and nitrogen/total phosphorus ratio of 1.5 are necessary for optimal growth However, in our survey, we noted that 60 percent of the farmers applied no chemical fertilizer on their farms while only 40 percent could apply. Therefore 20 percent of the farmers faced challenges in cocoa production due to inadequate finances to purchase farms inputs. With the advent of technology, there is the availability of modern equipments that can facilitate the process of cocoa production, some of which include; ovens for drying cocoa and electronic spray. We can observe from our survey that only 14.7 percent of our respondents used modern equipments while $85.3 \%$ did not use, making up a percentage point of 70.6 percent farmers who faced challenges in producing cocoa as a result of non-usage of modern equipment.

Table 5. Challenges faced by Cocoa producers in Santchou Cocoa Zone

\begin{tabular}{lcccc}
\hline \multicolumn{1}{c}{ Factors } & $\begin{array}{c}\text { Total } \\
\text { Observation }\end{array}$ & $\begin{array}{c}\text { Non } \\
\text { Challenge }\end{array}$ & Challenge & $\begin{array}{c}\text { Percentage } \\
\text { Différence }\end{array}$ \\
\hline Financial Status & 150 & 45.3 & 54.7 & $(9.4)$ \\
Agricultural Training & 150 & 22.3 & 76.7 & $(54)$ \\
Level Of Education & 150 & 4 & 96 & $(92)$ \\
Farm Size & 150 & 16.7 & 83.3 & $(66.6)$ \\
Chemical/Fertilizer Application & 150 & 40 & 60 & $(20)$ \\
Modern Equipment & 150 & 14.7 & 85.3 & $(70.6)$ \\
Climate Change & 150 & 8.7 & 91.3 & $(82.3)$ \\
Bank Account & 150 & 22.7 & 77.3 & $(54.6)$ \\
Experience & 150 & 96.9 & 3.1 & 93.8 \\
\hline
\end{tabular}

Source: Author from field survey

Cocoa plants thrive well under temperatures between 21 and $23^{\circ} \mathrm{C}$, and require a fairly constant rainfall of 1,000 mm or more per year (Robiglio et al., 2010). However, from our survey, most of our respondents complained that climate always affect their production especially in years during which the dry season is harsh like this year or when the rains are too heavy. Going by our table above, 91.3 percent of farmers were affected by climate change as against 8.7 percent who were not given their farms are located in relatively swampy areas that are well drained. This thus gives us 82.3 percent of farmers who face challenges in cocoa production because of climate change. Agricultural credit 


\section{International Journal of Business Economics (IJBE)}

Vol, 2 Issue 1, pp 1-17, Sept 2020

http:/ /jurnal.umsu.ac.id/index.php/ijbe

eISSN 2686-472X

schemes are indispensable to assist farmers to acquire basic agricultural tools, improve planting material, hire labour and transport facilities. One of the means of easily having access to credit is by being an account holder who saves regularly too. But from our survey, 77.3 percent of the farmers do not even own bank accounts given their poverty level. The proportion who owned and at least save something was 22.3 percent, thus making up a percentage difference of 54.6 percent of famers who faced challenges in their farming activities. This is because owning a bank account is a prerequisite to obtaining credit. Recently, most cocoa farmers rely on the rotatory loans and saving groups which are owned and operated by the communities themselves and cannot provide adequate funds to all farmers. Source of finance is therefore a major handicap in cocoa production in particular and agriculture in general in the country.

In addition to the above, experience is often seen as the best teacher. This implies that the more one does a particular thing, the more the person will be apt to doing it. In this light, we captured the ages of farmers as their years of experience. However, going by our table 10 above, just 3.1 percent of the sampled cocoa farmers say that they were not experienced enough whereas 96.9 percent of the farmers did not see experience as a challenge to their farming activities. In this perspective, it can therefore be concluded that 93.8 percent of the respondents never saw experience as a challenge in their production activities. Besides, cocoa producers in the study area did complain of some key issues not captured in our questionnaires such as Cheating through weighing scale adjustments by cocoa purchasing clerks which earn them a lower income, thus discouraging them. They equally mentioned the poor state of roads was really a big challenge, making transportation costly and therefore the overall process of cocoa production. In addition was the issue of the market being full of fake agrichemicals which are difficult to detect by them ordinary cocoa farmers. Most of these cocoa producers said that there are many fake chemicals in the market most especially for the black pod disease which after haven applied did not clear it off. The only solution was to get help from agricultural extension officers but with extra cost.

\section{Conclusion}

This study has attempted to study the role of social capital in promoting cocoa production in Santchou sub division. The importance of social capital is another new stylized fact in promoting agriculture which in turn is going to reduce poverty rate, improvement in welfare, reduce the dependency rate and solve the problem of unemployment. The objectives targeted were: to analyze the socio-economic characteristics of cocoa producers, to examine the impact of social capital in the enhancement of cocoa production, to explore the determinants of social capital and to determine the challenges faced by cocoa producers in Santchou.

Methodologically, we used a set of social capital related variables (family ties, association of colleagues, belonging to a religious group, professional and friendship association....) to constructed a social capital index through the application of Multiple Correspondence Analysis as originally proposed by World Bank (2009). Using primary data collected amongst 150 cocoa farmers selected from ten villages heavily involved in cocoa production within the Santchou cocoa zone, the probit model was use to estimate our result. 


\section{International Journal of Business Economics (IJBE)}

Vol, 2 Issue 1, pp 1-17, Sept 2020

http://jurnal.umsu.ac.id/index.php/ijbe

eISSN 2686-472X

The result revealed a strong correlation between social capital and agricultural production while level of education, sex, marital status, financial status, experience in farming, household size and agricultural training are strongly corroborating with the determinants of social capital. Meanwhile farm size, level of education, application of farm inputs (pesticides and fertilizers), modern equipment, climate change, access to credit, land tenure system were observed to the major challenges faced by cocoa farmers in Santchou cocoa zone. In terms of socio-economic policies, we recommend that civil society members and stake holders should join associations that can leave off their financial constraints. Therefore, social network connections of cocoa farmers should be improved further to enable them easily get assistant in times of need.

\section{REFERENCES}

Adepoju A and Oni O (2012). Investigating Endogeneity Effects of Social Capital on Household Welfare in Nigeria: A Control Function. Approach Quarterly Journal of International Agriculture Vol 51(1) pp 73-96.

Abayomi S O (2012). Impact of Climate Change on Cocoa Agriculture and Technical Efficiency of Cocoa Farmers in South-West Nigeria. J Hum Ecol, 40(2): 143-148

Agboola W, Yusuf SA and Oloniniyi MT (2016). Effect of Social Capital and Access to Microcredit on Productivity of Arable Crop Farmers in Kwara State, Nigeria. A Journal of Agriculture and Veterinary Science; Vol 9, p 09-16

Ajani I Y and Tijani G A (2014). The role of social capital in access to microcredit in Ekiti state, Nigeria. Pakistan Journal of Social Sciences 6 (3), 2009, 125- 132Sciences, 3(2), 2014, 175-196.

Akpabio I A (2008). Significant predictors of social capital in farmers' organization in AkwaI-bom, Nigeria. Journal of International

Amin A (2001). Rural Poverty and Agricultural Development in Cameroon, Collège par la Cahine UNESCO (Université Montesquieu-Bordeau Paris).

Asselin, LM (2005). "Multidimensional Poverty Measurement with Multiple Correspondence Analysis." Paper presented at the International conference: the Many Dimensions of Poverty.

Blau DF and Grossberg JA (1990). Maternal labour supply and children's cognitive Development; National Bureau of Economic Research, working paper No. 3536

Becker G S (1965). A theory of the allocation of time, The Economic Journal 75(299): 493-517.

Bogetic Z, Bussolo X, Medvedev D, Wodon Q and Boakye D (2007). Ghana's growth story: How to accelerate growth and achieve MDGs? Background paper for Ghana's Country Economic Memorandum, World Bank, Washington D.C.

Bowles S and Gintis H (2002). "Social capital and community governance." The Economic Journal, 112: F419-F436.

Bulir A (1998). The price incentive to smuggle and the cocoa supply in Ghana, 1950-96.

Cramb R A (2004). The role of social capital in the promotion of conservation farming: the case of landcare in the southern Philippines ISCO $2004-13^{\text {th }}$ International Soil Conservation Organization Conference - Brisbane, July 2004

Cordaro F and Desdoigts A (2016). Learning versus status quo bias and the role of social capital in technology adoption: The case of cocoa farmers in Côte d'Ivoire. Policy brief $n^{\circ} 160$. 


\section{International Journal of Business Economics (IJBE)}

Vol, 2 Issue 1, pp 1-17, Sept 2020

http://jurnal.umsu.ac.id/index.php/ijbe

eISSN 2686-472X

Coulibaly N (2012). Faire de la Cacaoculture une activité Rentable. Conférence Mondiale du Cacao en Côte d'Ivoire. 19-23 novembre.

Grootaert C and Vertun A (2014) Understanding and measuring social capital. A multidisciplinary tool for practitioners.Directions in Development. World Bank, Washington DC

Dasgupta P (2002). Economic progress and the idea of social capital. Journal of Biotechnology

Efombagn M, Sounigo O, Nyassé S, Dauleux M, Cilas C, Eskes A and Allen M (2006). Genetic diversity in cocoa germplasm of southern Cameroon revealed by simple sequences repeat markers. African Journal of Biotechnology 5(16):1441-1449

Frijters P, David W. Johnston, Manisha Shah and Michael A. Shields. (2008). To Work or Not to Work? Child Development and Maternal Labor Supply. November, 2008

Fule C B (2013). Small-scale versus large-scale cocoa farming in Cameroon: which farm type is more ready for the future? Agricultural Food and Environmental Policy Analysis No 829 pp 1401-4084.

Galawat and Yobe T, (2011). Does Market Liberalization Jeopardize Export Quality? Cameroonian Cocoa, 1995-2000

Iyanda J, Afolami C, Obayelu J and Ladebo O (2014). Social Capital and Access to Credit among Cassava Farming Households in Ogun State, Nigeria. Journal of Agriculture and Environmental Sciences, 3(2), pp 175-196

Killick T (1999). Economic change and the welfare of the rural poor. A report prepared for IFAD Rural poverty Report.

Laan H L and Haaren W T (1990). African Marketing Boards under Structural Adjustment: the experience of Sub-Saharan Africa during the 1980s. African Studies Centre Leiden, Working paper, No 13

Lawal J O, Tomonona B, Ajani Y and Oni A (2009). Effects of social capital on credit access among Cocoa farming household in Osun State, Nigeria. Agricultural Journal. Vol 4(4), pp184-191,

Nikaido H I (2004). Commodities under neoliberalism: the case of cocoa. G-24 Discussion Paper Series, UNCTAD No 1, 2004

Njong A M and Ningaye P (2008). Characterizing Weights in Measurement of Multidimensional Poverty: An application of Data Driven Approaches to Cameroonian Data: OPHI Working Paper 21.

Nyemeck JB, Gockowski Y and Nkamleu GB (2007). Paper Presented to African Association of Agricultural Economist (ANAE) Accra, Ghana.

Pretty R. D. (2003). The prosperous community-social capital and public life, American prospect (13) pp 35-42.

RobiglioV, Ngendakumana S, Gockowski J, Yemefack M, Tchienkoua M, Tchawa P, Tchoundjeu $\mathrm{Z}$ and Bolognesi M (2010). Reducing emissions from all land uses in Cameroon. Final national report. Nairobi, Kenya: ASB partnership for the tropical forest margins.

Sentumbwe S (2007) soils, plant growth and crop production - Vo.III - Growth and Production of Cacao

Vos G, Krauss U, Petithuguenin P, Perreira L and Nanga C (2002). Global Co-ordination Group on Sustainable cocoa Economy: Achieving more efficient knowledge transfer. Social Research 1(3) 2008, 61-70 


\section{International Journal of Business Economics (IJBE)}

Vol, 2 Issue 1, pp 1-17, Sept 2020

http:/ /jurnal.umsu.ac.id/index.php/ijbe

eISSN 2686-472X

Wambugu S, Julius J. Okello and Rose A, yikal A (2009). Effect of Social Capital on Performance of Smallholder Producer Organizations: The Case of Groundnut Growers in Western Kenya Contributed. A Paper prepared for presentation at the International Association of Agricultural Economists Conference, China, August 1622.

Wokia-azi N., Kumase, Hernes B and Stephen K (2008). A Gendered Analysis of Cocoa Production in Southern Cameroon. A Final Draft in Opportunities and Constraints. Working paper No 8

Wolz T, Agrey K and Kalimang'asi N (2014) Technical Efficiency of Cocoa Production through Contract Farming: Empirical Evidence from Kilombero and Kyela Districts International Journal of Scientific and Research Publications, Vol 4(10), October. www.ijsrp.org.

World Bank (1999) what is social capital? Poverty Net htttp://www.worldbank.org/ poverty /scapital/whats.htm. 